\title{
Studies of Sorbent Efficiencies of Maize Parts in Fe(II) Removal from Aqueous Solutions
}

\author{
Chidi Edbert Duru ${ }^{1, \mathrm{a}^{*}}$ and ljeoma Akunna Duru ${ }^{2, \mathrm{~b}}$ \\ 1 Department of Chemistry, Imo State University P.M.B. 2000, Owerri Imo State, Nigeria. \\ ${ }^{2}$ Department of Chemistry, Federal University of Technology, Owerri, \\ P.M.B. 1526, Owerri Imo State, Nigeria. \\ achidiedbertduru@gmail.com, bakunnaobiji@yahoo.com
}

\begin{abstract}
Keywords: Maize, Biomass, Sorption, Percentage removal, Iron(II), Adsorption capacity.
\end{abstract}
\begin{abstract}
The efficiency of the cob, sheath, seed chaff and stalk of maize plant in the removal of $\mathrm{Fe}(\mathrm{II})$ from aqueous solutions was studied. FTIR analysis of biomass surfaces before and after adsorption showed that seed chaff has the highest number of functional group coordination points. The percentage removal of $\mathrm{Fe}(\mathrm{II})$ increased with increase in $\mathrm{pH}$ for all the biomass parts with highest efficiency shown by the seed chaff at all the studied $\mathrm{pH}$ values. Metal up-take also increased with increase in seed chaff load. This direct relationship was however not shown by other parts where decreases in metal up-take were observed at high doses of the biomass. At optimum $\mathrm{pH}$ and biomass load, equilibrium adsorption capacities were reached in 30 minutes for all the parts. The efficiency of the biomass parts in the sorption process were in the order seed chaff $>$ stalk $>$ sheath $>$ cob. At optimum conditions of the study, the seed chaff removed $73 \%$ of $\mathrm{Fe}(\mathrm{II})$ from solution in its natural state.
\end{abstract}

\section{Introduction}

Water pollution by heavy metals has been a major problem in recent times due to the rapid industrialization of the modern world. With the growth of industrial activities, contamination of the environment with wastewater and heavy metals has become a major problem [1]. Iron ion is an important corrosion product that is commonly found in fluids of industrial discharges. In drinkingwater supplies, iron(II) salts are unstable and are precipitated as insoluble iron(III) hydroxide which settles out as a rust-coloured silt. Anaerobic ground waters may contain iron(II) at concentrations of up to several milligrams per litre without discolouration or turbidity in the water when directly pumped from a well, although turbidity and colour may develop in piped systems at iron levels above $0.05-0.1 \mathrm{mg} / \mathrm{L}$. Staining of laundry and plumbing may occur at concentrations above $0.3 \mathrm{mg} / \mathrm{L}$. Iron also promotes undesirable bacteria growth (iron bacteria) with a distribution system which results in the deposition of a slimy coating on the piping [2].

Conventional techniques aimed at removing heavy metals usually include chemical precipitation, ion exchange, membrane process, crystallization, and electrochemical treatment [3]. These processes may be ineffective or expensive, especially when the heavy metal ions are contained in solution at concentrations ranging from 1-100 mg/L. Agro-wastes are now being studied for use as adsorbents because of their abundant availability and low cost owing to their relatively high fixed carbon content and the presence of porous structure. Byproducts of agriculture or wood processing are cost-effective and environmentally-benign means to remove heavy metals from water [4].

Although many investigations have been conducted on the ability of some biomass or waste materials to remove Fe(III) from aqueous solutions [5-14], only a few investigators have studied Fe (II) biosorption. In these studies attention have been focused on carbonaceous materials from biomass and animal parts like crab shell [15], bark of a tree [16], wooden charcoal [17], while few used unmodified biomass waste [18-19]. Recently, studies on the removal of Fe(II) from aqueous solutions have been conducted using synthesized and chemically modified materials. Novel synthetic siliceous waste sorbents with $99.8 \% \mathrm{Fe}(\mathrm{II})$ removal efficiency have been studied [20]. 
Also the use of manganese oxide and iron oxide coated zeolite [21] and modified phosphate dolomite [22] as sorbents have been reported. The application of these materials though with good iron(II) percentage removal would be financially challenging especially in rural areas where this type of contamination is often time prevalent.

This paper studies and compares the iron(II) removal efficiency of maize waste parts namely cob, seed chaff, stalk and sheath in their natural forms. Their removal efficiencies at optimum study conditions would also be considered.

\section{Methodology}

\section{Reagents and solution preparation}

All chemicals used were of analytical reagent grade and purchased from Finlab Nigeria Ltd Owerri, Nigeria. A freshly prepared stock solution of ferrous chloride $(1000 \mathrm{mg} / \mathrm{L})$ was used as adsorbate and a solution of $50 \mathrm{mg} / \mathrm{L}$ were obtained by diluting the stock solution with distilled water.

\section{Collection and preparation of biosorbent}

Fully mature maize crops were collected from a farm in Eziobodo in Ihiagwa, Owerri West, Imo State Nigeria. They were washed repeatedly with distilled water to remove dust and soluble impurities. The different parts of the plant which comprised of sheath, stalk, cob and seeds were separated and cut into small pieces. The seeds were crushed and washed through a sieve to remove the starch they contain. These parts were then dried for 5 hours in a conventional oven at a temperature of $100{ }^{\circ} \mathrm{C}$. The dried parts were crushed with a mechanical grinder to a fine powder which was passed through a sieve of 30 mesh and stored in a plastic bottle for further use.

\section{Instrumentation}

Characterization of biosorbent was done with Fourier-transform infrared spectrophotometer (FTIR) Agilent Cary 630. Pressed pellets were prepared by grinding the powdered specimens with spectroscopic grade $\mathrm{KBr}$. Characterization was done before and after the biosorption process. The concentrations of $\mathrm{Fe}(\mathrm{II})$ in the different solutions were determined using HI 83200 Multiparameter Bench Photometer by HANNA Instruments.

\section{Adsorption studies}

Batch adsorption tests were conducted in triplicates to determine the effect of different parameters i.e.; $\mathrm{pH}$, adsorbent dosage and time for maximum removal of $\mathrm{Fe}$ (II) from solution by the different parts of maize biomass.

\section{Effect of pH on adsorption}

The different parts of maize biomass; cob, sheath, stalk and seed chaff of weight $0.2 \mathrm{~g}$ were added to $50 \mathrm{~mL}$ of $50 \mathrm{mg} / \mathrm{L} \mathrm{Fe}(\mathrm{II})$ solutions in glass reactors. Solutions with $\mathrm{pH}$ values ranging from $1.0-4.0$ were prepared in triplicates. This $\mathrm{pH}$ range was used for the study because the precipitation of metal ions occurred simultaneously at $\mathrm{pH}$ higher than 6 [23-24]. They were covered with aluminum foils and shaken for 120 minutes with a digital shaker. After this time the suspensions were filtered and the concentration of $\mathrm{Fe}(\mathrm{II})$ in the filtrates were measured.

\section{Effect of adsorbent dose on adsorption}

This study was carried out at the optimum $\mathrm{pH}$ obtained for each biomass part. $50 \mathrm{~mL}$ of $50 \mathrm{mg} / \mathrm{L} \mathrm{Fe}(\mathrm{II})$ solutions at optimum $\mathrm{pH}$ were transferred in four glass reactors set in triplicates. Adsorbent masses of $0.1 \mathrm{~g}, 0.2 \mathrm{~g}, 0.4 \mathrm{~g}$ and $0.8 \mathrm{~g}$ were then added. They were covered with aluminum foils and shaken for 120 minutes with a digital shaker. After this time the suspensions were filtered and the concentration of $\mathrm{Fe}(\mathrm{II})$ in the filtrates were measured. 


\section{Effect of contact time}

The dependence of metal uptake by biomass adsorbents as a function of time was determined at the optimum $\mathrm{pH}$ and adsorbent dose obtained for each biomass part. Five glass reactors containing $50 \mathrm{~mL}$ of $50 \mathrm{mg} / \mathrm{L} \mathrm{Fe}$ (II) solutions at the optimum $\mathrm{pH}$ and biomass load for each part were prepared in triplicates. They were covered with aluminum foils and shaken with a digital shaker. A set was removed every 15 minutes and the suspensions were filtered and concentrations of $\mathrm{Fe}(\mathrm{II})$ in the filtrate were measured. This process was carried out for a period of 120 minutes.

\section{Evaluation of biosorption efficiency}

Concentrations of $\mathrm{Fe}$ (II) in the filtrates were determined by diluting each sample to a ratio of 1:50, enabling reading and analysis of the concentration of metal ions. The value of the percentage removal $(\gamma)$ of metal ions from solution was calculated from the equation [25]:

$$
\mathrm{y}=\frac{\mathrm{Co}-\mathrm{Ce}}{\mathrm{Co}} \times 100 \text {, }
$$

where $\mathrm{Co}$ and $\mathrm{Ce}$ are the initial and equilibrium concentrations of $\mathrm{Fe}(\mathrm{II})$ in the solutions $(\mathrm{mg} / \mathrm{L})$.

\section{Results and discussion}

Plant biomass or lignocellulose is composed of cellulose, hemicellulose and lignin. Different functional groups have been found on this material by researchers [26-31] and are shown in table 1.

FTIR scans of the maize biomass parts used in this study before and after metal ion up-take are shown in Fig. 1a-1d and the shifts in absorption bands of the functional groups compared in table 2 .

Table 1. Organic groups found on the different biomass materials.

\begin{tabular}{|l|l|l|}
\hline $\mathbf{c m}^{-1}$ & \multicolumn{1}{|c|}{ Organic Group } & \multicolumn{1}{c|}{ References } \\
\hline 3350 & O-H & Xu et al. [26], Carmago et al. [27] \\
\hline 2900 & C-H & Riyajan and Intharit [28], Filho et al. [29] \\
\hline 2850 & $\mathrm{OCH}_{3}$ & Carmago et al. [27] \\
\hline 1710 & $\mathrm{HO}-\mathrm{C}=\mathrm{O}$ carboxylic acid & Guo et al. [30] \\
\hline 1620 & $\mathrm{C}=\mathrm{O}$ ketone & Guo et al. [30] \\
\hline 1600 & $\mathrm{C}-\mathrm{H}$ vibration of aromatic ring & Guo et al. [30] \\
\hline 1390 & O-H phenolic & Xu et al. [26] \\
\hline 1200 & $\mathrm{C}-\mathrm{O}$ and $\mathrm{C}=\mathrm{O}$ stretching & Sun et al. [31] \\
\hline 1150 & O-C=O & Guo et al. [30] \\
\hline 1030 & C-O-C & Xu et al. [26] \\
\hline 850 & $\begin{array}{l}\beta-\text { glycosidic bonds between } \\
\text { sugars }\end{array}$ & Xu et al. [26] \\
\hline
\end{tabular}
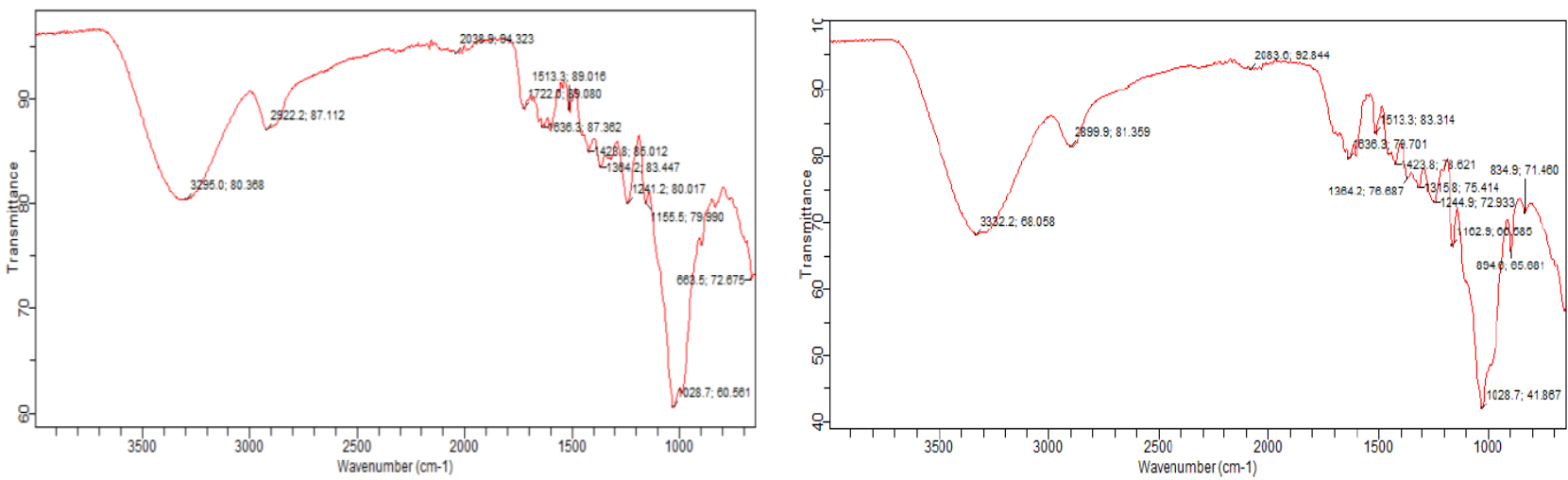

Figure 1a. FTIR spectra of maize cob before and after adsorption. 

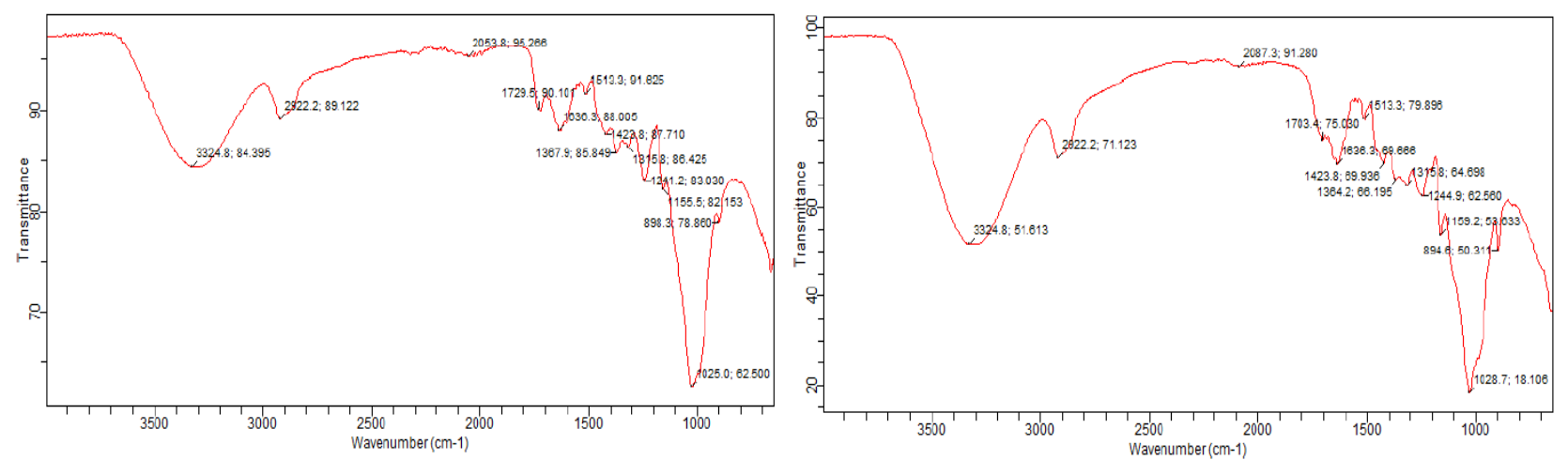

Figure 1b. FTIR spectra of maize sheath before and after adsorption.
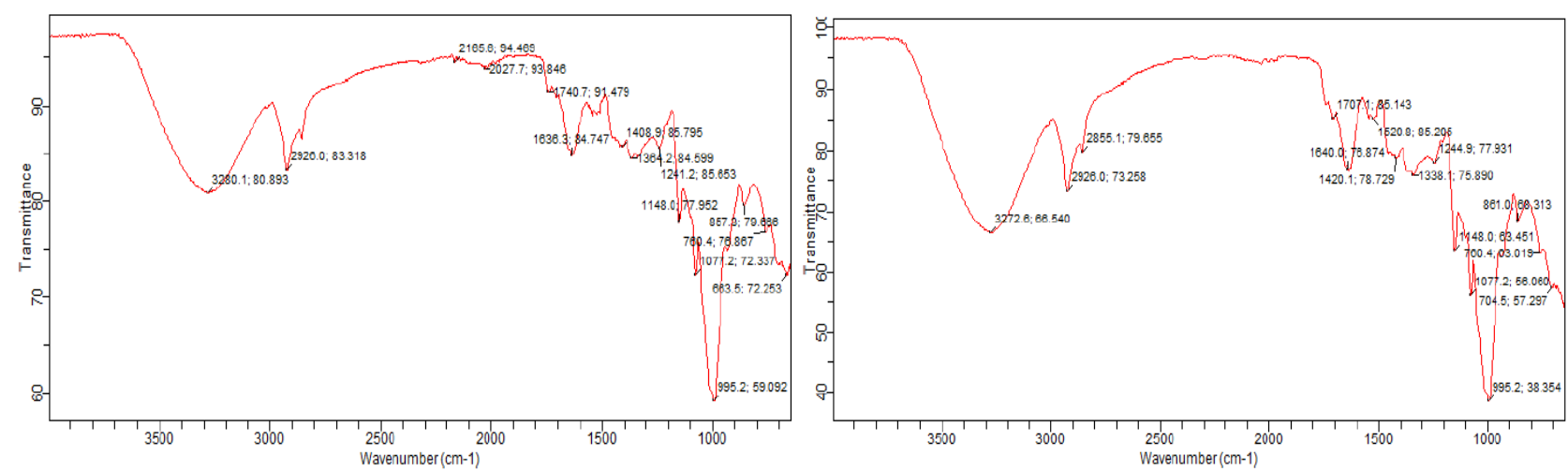

Figure 1c. FTIR spectra of maize seed chaff before and after adsorption.
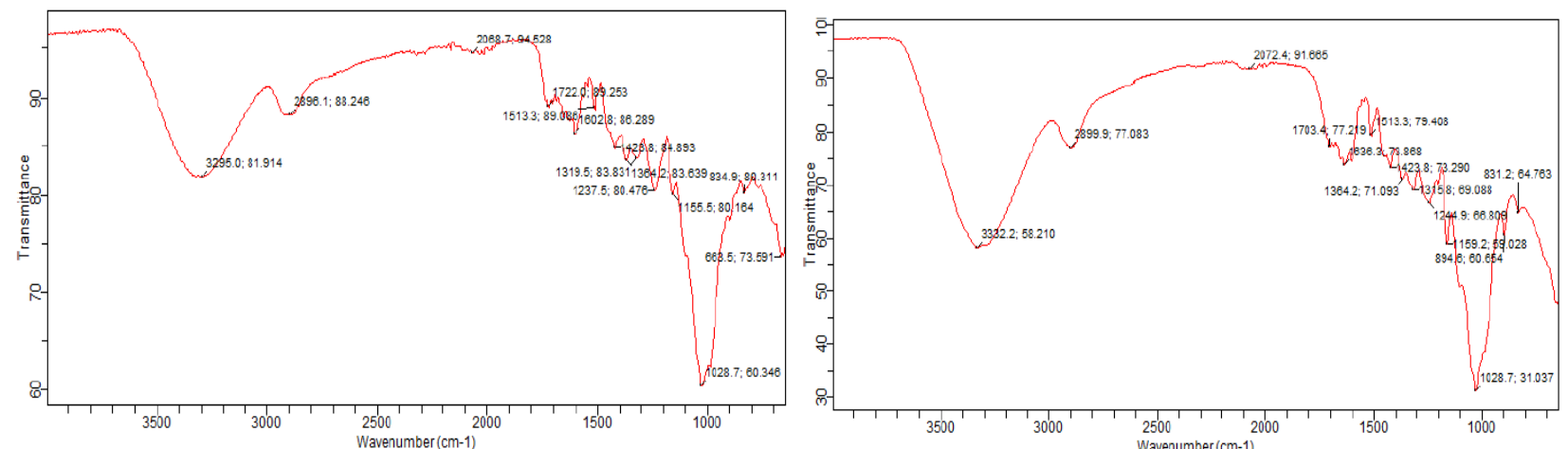

Figure 1d. FTIR spectra of maize stalk before and after adsorption.

Table 2. Comparison of shifts in absorbance of organic groups in maize biomass before and after adsorption.

\begin{tabular}{|l|l|l|l|l|l|l|}
\hline Adsorption & Part & $\mathbf{O - H}$ & $\mathbf{O C H}_{3}$ & $\mathbf{H O}-\mathbf{C}=\mathbf{O}$ & $\mathbf{C}=\mathbf{O}$ & O-H-Ar \\
\hline \multirow{3}{*}{$\begin{array}{l}\text { Before } \\
\text { adsorption }\end{array}$} & Cob & 3295 & 2922 & 1722 & 1636 & 1364 \\
\cline { 2 - 7 } & Sheath & 3324 & 2922 & 1729 & 1636 & 1367 \\
\cline { 2 - 7 } & Seed & 3280 & 2920 & 1740 & 1636 & 1364 \\
\cline { 2 - 7 } & Stalk & 3295 & 2896 & 1722 & 1602 & 1319 \\
\hline \multirow{4}{*}{$\begin{array}{c}\text { after } \\
\text { adsorption }\end{array}$} & Cob & 3332 & 2899 & 1704 & 1636 & 1364 \\
\cline { 2 - 7 } & Sheath & 3324 & 2822 & 1703 & 1636 & 1364 \\
\cline { 2 - 7 } & Seed & 3272 & 2855 & 1707 & 1622 & 1338 \\
\cline { 2 - 7 } & Stalk & 3332 & 2899 & 1703 & 1636 & 1364 \\
\hline
\end{tabular}

The shift in FTIR absorption bands to lower frequencies indicates the involvement of the functional groups on the biomass in coordination with $\mathrm{Fe}(\mathrm{II})$ [32]. The functional groups involved in the coordination with $\mathrm{Fe}(\mathrm{II})$ in the biomass parts where cob- $\mathrm{OCH}_{3}, \mathrm{HO}-\mathrm{C}=\mathrm{O}$, sheath- $\mathrm{OCH}_{3}$, $\mathrm{HO}-\mathrm{C}=\mathrm{O}$, O-H-Ar, seed- $\mathrm{OH}, \mathrm{OCH}_{3}, \mathrm{HO}-\mathrm{C}=\mathrm{O}, \mathrm{C}=\mathrm{O}, \mathrm{O}-\mathrm{H}-\mathrm{Ar}$ and stalk- $\mathrm{HO}-\mathrm{C}=\mathrm{O}$. The maize seed chaff had the most number of functional group sites for coordination with $\mathrm{Fe}(\mathrm{II})$. 
The percentage removal of $\mathrm{Fe}(\mathrm{II})$ from solution by the different biomass parts as a function of pH is shown in Fig. 2.

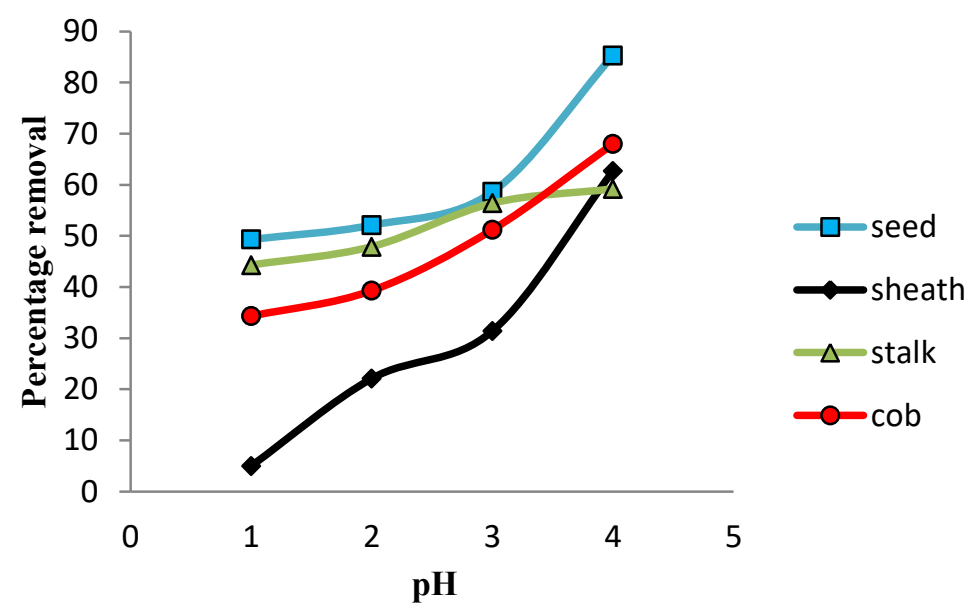

Figure 2. Plot of $\mathrm{pH}$ vs percentage removal of $\mathrm{Fe}^{2+}$ by $0.2 \mathrm{~g}$ of different biomass parts.

All parts of the biomass studied showed an increase in the up-take of $\mathrm{Fe}(\mathrm{II})$ as $\mathrm{pH}$ of the solution increased. Metal adsorption by the stalk was uniform and steady for all the studied $\mathrm{pH}$ values. The other parts showed a rapid increase in metal uptake after $\mathrm{pH}$ of 3 . At low $\mathrm{pH}$ values (1.0-3.0) more $\mathrm{H}_{3} \mathrm{O}^{+}$ions will be available to compete with the $\mathrm{Fe}(\mathrm{II})$ ions in solution for the adsorption sites of the biosorbents. Also at low $\mathrm{pH}$ most of the functional groups on the biomass are protonated [33]. This will reduce the number of binding sites available for the adsorption of Fe(II) ions. The $\mathrm{pH}$ can also affect the solution chemistry. In acidic $\mathrm{pHs}, \mathrm{Fe}(\mathrm{II})$ ions remain with the positive charge, but in alkaline pHs, the hydroxide ions $\left(\mathrm{OH}^{-}\right)$cause precipitation of $\mathrm{Fe}(\mathrm{II})$ in the form of $\mathrm{Fe}(\mathrm{OH})_{2}$ leading to decrease in ion concentration in solution not dependent on adsorption.

The effect of biomass load on the percentage removal of Fe(II) from solution by the different biomass parts is shown in Fig. 3.

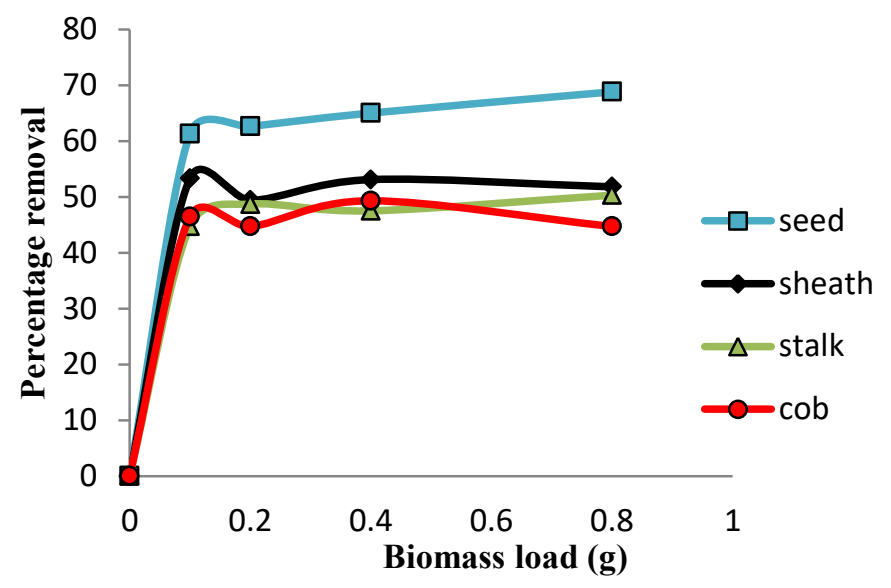

Figure 3. Plot of percentage removal of $\mathrm{Fe}^{2+}$ ions vs Biomass load by different biomass parts at $\mathrm{pH} 4$.

It is plausible that at higher adsorbent dose, there would be more exchangeable sites for the metal ions [34]. This was observed in the seed chaff which showed a steady increase in metal uptake with increase in biomass load, and removed $70 \%$ of the ions from solution at $0.8 \mathrm{~g}$ load. However, the adsorption capacity of the other maize biomass parts did not conform to this linearity and showed a consistent alternating increase and decrease in metal removal efficiency as biomass load increased. These observations maybe due to overlap of adsorption sites, arising from overcrowding of adsorbent particles [35]. Also the high adsorbent dose could impose a screen effect 
of the dense outer layer of the cells, thereby shielding the binding sites from the metal ions [36]. For sheath, stalk and cob best metal removal were achieved at $0.1 \mathrm{~g}, 0.8 \mathrm{~g}$ and $0.4 \mathrm{~g}$ respectively.

The time for the equilibrium adsorption of the biomass materials for the different adsorbents at $\mathrm{pH} 4$ and optimum biomass load are shown in Fig. 4.

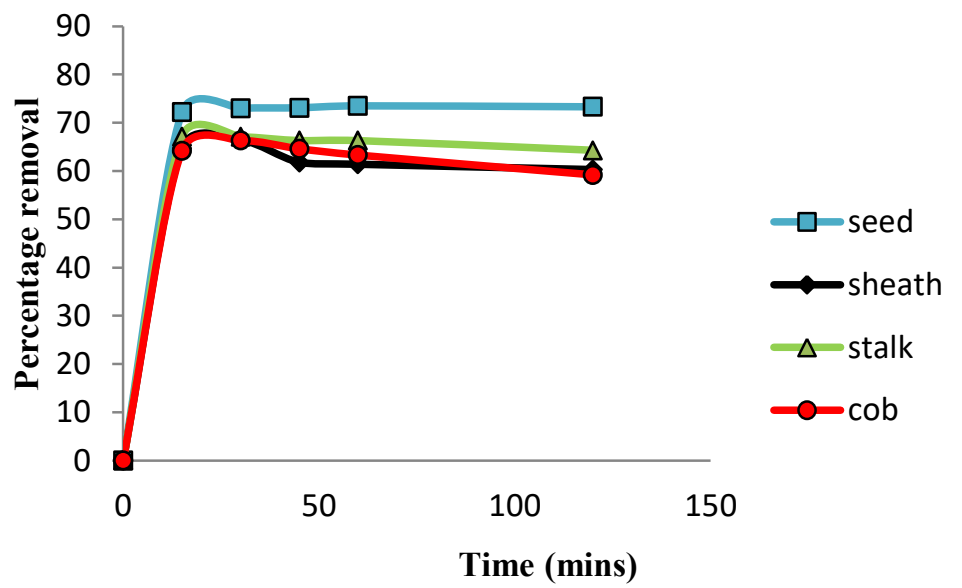

Figure 4. Plot of Contact time vs percentage removal of $\mathrm{Fe}^{2+}$ by different biomass parts at $\mathrm{pH} 4$.

Most literature works on the biosorption of Fe(II) from aqueous solutions use carbon, ash, charcoal, minerals or synthetic materials as adsorbents. The percentage removals of $\mathrm{Fe}(\mathrm{II})$ in some of these studies under different conditions gave best values as $82 \%$ in 50 minutes at $\mathrm{pH} 6$ [37], $97 \%$ in 90 minutes at $\mathrm{pH} 5$ [38] and $99.8 \%$ in 40 minutes at $\mathrm{pH} 2$ [20]. For all the biomass parts used in this study, the adsorption of $\mathrm{Fe}$ (II) increased with increase in contact time. Equilibrium adsorption was reached in approximately 30 minutes for all the parts. The efficiency of the biomass parts in the sorption process were in the order seed, stalk, sheath and cob with values $73 \%, 67.1 \%$, $66.4 \%$ and $66.3 \%$ respectively. The percentage removal of $\mathrm{Fe}(\mathrm{II})$ after 30 minutes for all the biomass parts was either constant or decreased as more time was allowed for the process. The decrease in the adsorption quantity after 30 minutes suggests a possible double layer adsorption of the metal ions by weak electrostatic forces between the second layer of ions and the first layer. For the seed however, Fe(II) concentration remained constant after 30 minutes up to 120 minutes, which suggests a possible monolayer adsorption of the ions without intermolecular interactions.

\section{Conclusion}

This study has shown that maize biomass can be successfully applied for the removal of Fe(II) ions from aqueous solutions. Though the parts of the plant have similar functional groups, their efficiencies in the removal process differ. The seed chaff which is a waste product in maize starch extraction for domestic and industrial applications is a veritable material for the sorption of $\mathrm{Fe}$ (II) from solution with a biosorption efficiency of $73 \%$ in its natural and unmodified form.

\section{References}

[1] K.C. Sekhar et al., Removal of heavy metals using a plant biomass with reference to environmental control, Int. J. Miner Process. 68 (2003) 37-45.

[2] Department of National health and Welfare Canada, Nutrition recommendations, the report of the Scientific Review Committee, Ottawa, 1990.

[3] S. Babel, T.A. Kurniawan, Low-cost adsorbents for heavy metals uptake from contaminated water: a review, J. Hazard Mater. 97 (2003) 219-243. 
[4] T.L. Eberhardt, S.H. Min, Biosorbents prepared from wood particles treated with anionic polymer and iron salt: Effect of particle size on phosphate adsorption, Bio. Tec. 99 (2008) 626-630.

[5] R. Razmovski, M. Šciban, Iron (III) biosorption by Polyporus squamosus, Afr. J. Biotec. 7 (2008) 1693-1699.

[6] A. García-Mendieta, M.T. Olguín, M. Solache-Ríos, Biosorption properties of green tomato peel (Physalis philadelphica Lam) for iron, manganese and iron-manganese from aqueous systems, Desalination. 284 (2012) 167-174.

[7] N.T. Abdel-Ghani et al., Factorial experimental design for biosorption of iron and zinc using Typha domingensis phytomass, Desalination. 249 (2009) 343-347.

[8] M. Tuzen et al., Biosorption of copper (II), lead (II), iron (III) and cobalt (II) on Bacillus sphaericus-loaded Diaion SP-850 resin, Anal. Chim. Acta. 581 (2007) 241-246.

[9] A. Selatnia et al., Biosorption of $\mathrm{Fe}^{3+}$ from aqueous solution by a bacterial dead Streptomyces rimosus biomass, Proc. Biochem. 39 (2004) 1643-1651.

[10] M. Aryal, M. Ziagova, M. Liakopoulou-Kyriakides, Study on arsenic biosorption using Fe(III)-treated biomass of Staphylococcus xylosus, Chem. Eng. J. 162 (2010) 178-185.

[11] Y. Sag, T. Kutsal, The simultaneous biosorption of $\mathrm{Cr}(\mathrm{VI}), \mathrm{Fe}(\mathrm{III})$ and $\mathrm{Cu}(\mathrm{II})$ on Rhizopus arrhizus, Proc. Biochem. 33 (1998) 571-579.

[12] V. Lugo-Lugo et al., Biosorption of $\mathrm{Cr}(\mathrm{III})$ and $\mathrm{Fe}(\mathrm{III})$ in single and binary systems onto pretreated orange peel, J. Environ. Manage. 112 (2012) 120-127.

[13] Z. Aksu, U. Açikel, Modelling of a single-staged bioseparation process for simultaneous removal of iron (III) and chromium (VI) by using Chlorella vulgaris, Biochem. Eng. J. 4 (2000) 229-238.

[14] A. Saravanan et al., Kinetics and isotherm studies of mercury and iron biosorption using Sargassum sp., Int. J. Chem. Sci. Appl. 1 (2010) 50-60.

[15] K.K.P. Porpino et al., Fe (II) adsorption on Ucides Cordatus crab shells, Quim. Nova. 34 (2011) 928-932.

[16] E.P. Rose, S. Rajam, Equilibrium study of the adsorption of iron (II) ions from aqueous solution on carbons from wild jack and jambul, Adv. Appl. Sci. Res. 3 (2012) 1889-1894.

[17] K. Ahamad, M. Jawed, Kinetics, equilibrium and breakthrough studies for Fe(II) removal by wooden charcoal: a low-cost adsorbent, Desalination. 251 (2010) 137-145.

[18] S.R. Shukla, R.S. Pai, A.D. Shendarkar, Adsorption of Ni(II), Zn(II) and Fe(II) on modified coir fibres, Sep. Purif. Technol. 47(3) (2006) 141-147.

[19] B. Acemioglu, Removal of Fe(II) ions from aqueous solution by Calabrian pine bark wastes, Bioresource Technol. 93 (2004) 99-102.

[20] I. Dahlan, S.R. Hassan, M.L. Hakim, Removal of Fe(II) from aqueous solutions using siliceous waste sorbent, Sustainable Environmental Research. 23(1) (2013) 41-48.

[21] M. Khashij et al., Removal of Fe(II) from aqueous solutions using manganese oxide coated zeolite and iron oxide coated zeolite, IJE Transactions B: Applications. 29(11) (2016) 15871594.

[22] A.I. Ivanets et al., Removal of $\mathrm{Zn}^{2+}, \mathrm{Fe}^{2+}, \mathrm{Pb}^{2+}, \mathrm{Cd}^{2+}, \mathrm{Ni}^{2+}$ and $\mathrm{Co}^{2+}$ ions from aqueous solutions using modified phosphate dolomite, Journal of Environmental Chemical Engineering. 2 (2014) 981-987. 
[23] R. Boota, H.N. Bhatti, M.A. Hanif, Removal of $\mathrm{Cu}(\mathrm{II})$ and $\mathrm{Zn}$ (II) using Lignocellulosic fiber derived from Citrus Reticulata (Kinnow) waste biomass, Separation Science and Technology. 44 (2009) 4000-4022.

[24] D. Reddy et al., Optimization of $\mathrm{Cd}(\mathrm{II}), \mathrm{Cu}(\mathrm{II})$ and $\mathrm{Ni}(\mathrm{II})$ biosorption by chemically modified Moringa olifera leave powder, Carbohydrate Polymers. 88 (2010) 1077-1086.

[25] A.A. Seolatto, C.J. Filho, D.L. Mota, Evaluation of the efficiency of biosorption of lead, cadmium and chromium by the biomass of Pequi fruit skin (Caryocar brasiliense Camb.), Chemical Engineering Transactions. 27 (2012) 73-78.

[26] Z. Xu et al., Enzymatic hydrolysis of pretreated soybean straw, Biomass Bioenergy. 31 (2007) 162-167.

[27] F.A. Camargo et al., Processing and characterization of composites of poly(3hydroxybutyrateco-hydroxyvalerate) and lignin from sugar cane bagasse, J. Compos. Mater. 46 (2012) 417-425.

[28] S. Riyajan, I. Intharit, Characterization of modified bagasse and investigation properties of its novel composite, J. Elast. Plast. 43 (2011) 513-528.

[29] G.R. Filho et al., Characterization of methylcellulose produced from sugarcane bagasse cellulose: Crystallinity and thermal properties, Polym. Degrad. Stab. 92 (2007) 205-210.

[30] G.L. Guo et al., Characterization of enzymatic saccharification for acid-pretreated lignocellulosic materials with different lignin composition, Enzyme Microb. Technol. 45 (2009) 80-87.

[31] R.C. Sun et al., Characterization of lignins from wheat straw by alkaline peroxide treatment, Polym. Degrad. Stab. 67 (2000) 101-109.

[32] T.P. Devi, R.K.H. Singh, Complexes of nickel (II) with the Schiff bases derived from the condensation of salicylaldehyde and bis-Ni(AMUH) ${ }_{2} \mathrm{Cl}_{2}$, Rasayan J. Chem. 3(2) (2010) 266270 .

[33] J.S. Al-Jariri, F. Khalili, Adsorption of $\mathrm{Zn}(\mathrm{II}), \mathrm{Pb}(\mathrm{II}), \mathrm{Cr}(\mathrm{III})$ and $\mathrm{Mn}$ (II) from water by Jordanian Bentonite, Desalination and Water Treatment. 21 (2012) 308-322.

[34] S. Babel, T.A. Kurniawan, Cr (IV) removal from synthetic wastewater using cocoanut shell charcoal and commercial activated carbon modified with oxidizing agents and/or chitosan, Chemosphere. 54 (2004) 951-967.

[35] V.K. Garg et al., Dye removal from aqueous solution by adsorption on treated sawdust, Bioresource Technology. 89 (2003) 121-124.

[36] M.P. Pons, C.M. Fuste, Uranium uptake by immobilized cells of Pseudomonas strain EPS 5028, Applied Microbiology Biotechnology. 39 (1993) 661-665.

[37] M.H. Elhussien, G.A. Hamid, Removal of $\mathrm{Fe}(\mathrm{II})$ and $\mathrm{Cu}(\mathrm{II})$ from aqueous solutions using activated carbon derived from wooden parts of mangifera indica by chemical activation with $\mathrm{ZnCl}_{2}$, International Journal of Emerging Technology and Advanced Engineering. 5(11) (2015) 156-164.

[38] Y. Zhang et al., Biosorption of Fe(II) and $\mathrm{Mn}$ (II) ions from aqueous solution by rice husk ash, BioMed Research International. (2014) 1-10. 